\title{
Two plus Four: Revisiting a diplomatic masterpiece that paved the way for German Reunification
}

\author{
Julius Georg Luy \\ German Ambassador to Myanmar
}

\section{I ntroduction by Dr J ohn Leslie ${ }^{1}$}

Dramatic events in Central Europe in Autumn 1989-particularly demonstrations on the streets of Leipzig and East Berlin-often overshadow the accounts of the highstakes diplomacy that ended the Cold War division of Germany and Europe. This account by a member of the West German team that negotiated the 'Two-plus-Four' Treaty between the two Germanies, France, the UK, Soviet Union and United States puts the spotlight on the monumental issues resolved in a frenetic period of diplomacy between February and J uly 1990. The treaty leading to German unification managed issues central to modern Europe's bloodiest conflicts-state sovereignty and national self-determination-by preserving and extending Western Europe's multilateral institutions. Negotiators trod a narrow path between sceptics in East and West, unifying Germany without undermining Europe's multilateral political and security order founded on NATO and the European Community. Rather than raising the German Question anew, the 'Two-plus-Four' Treaty unified Germany by extending eastward the Federal Republic's postwar commitments to the West. Ambassador Luy provides a first-hand account of how this fortuitous chain of events unfolded.

\section{Transcript of the Talk given by J ulius Georg Luy at the Christchurch Town Hall on November 25, 2010, as part of the EUCN annual conference "European Integration at 60: Progress, Problems, Perspectives."}

\section{Introduction ${ }^{2}$}

In early 1989 the GDR's Communist Party chief, Erich Honecker, expressed his confidence in the perpetuity of the Berlin Wall: "The Wall will be standing in 50 and even in 100 years, if the reasons for it are not removed." And in August 1989, in the run-up to the 40th anniversary of the German Democratic Republic the same

1 Lecturer in Political Science, Victoria University of Wellington.

2 This text presents the personal views of the author only. 
Honecker even rhymed: "Den Sozialismus in seinem Lauf halten weder Ochs noch Esel auf" ("Neither an ox nor a donkey is able to stop the progress of socialism.") Honecker was wrong on both statements. The socialism in Central and Eastern Europe and even in the Soviet Union had started to collapse long before - and the Berlin Wall collapsed for the same reason 3 months later. Less than one year after its 40th anniversary the GDR vanished from the political landscape of Europe.

Last 3rd October we celebrated 20 years of German Unity. That occasion reminds not only of the results, but as well of the historical processes which led to German Unity. The most famous and the most decisive one is the peaceful revolution set into motion by the East German citizens. They in fact were the driving force of the more technical processes leading to German unity - which are the internal (i.e. intra-german) and the external aspects of unification. The two processes were closely intertwined. The focus of today's talk is on $2+4$, i. e. the external aspects of unification. What makes the process and the result of $2+4$ worth to be revisited - even twenty years after its conclusion and implementation? $2+4$ addressed, bundled and settled major issues of 20th century foreign policy: the sovereignty of states, the right of peoples to national self-determination, cooperative arrangements for security and stability in sensitive geopolitical situations, the final settlement of World War II consequences in Central and Western Europe. All these aspects make $2+4$ a worthwhile exercise in studying diplomatic craftsmanship and political history.

\section{Collapse of the East European communist/ socialist regimes}

$2+4$ did not take place in a historical vacuum. In 1989 - the year when the German unification process started - East Germany and Eastern Europe were in a precarious phase of their history. In 1989 the open breakup of the communist system had just begun. The system evidently had not lived up to its promises - and even

Gorbachev'svigorous reforms by "glasnost" and "perestroika" in Russia could not save it anymore, proving right Gorbachev's famous remark "Life punishes the latecomer." The longstanding freedom and civil rights movements particularly in Poland (Solidarity) and in Czechoslovakia (Charta 77) had chartered a way on which many other East European countries followed.

In East Germany the situation was particularly backwards. The East-West partition went through one nation. It divided families, towns and regions, cut through an established society and - notwithstanding the war ravages - a promising national economy. Germans in the GDR always looked over the fence to Germany's other half. Therefore, by TV, radio, by family relations and by smuggled books and newspapers they were well aware, that the pastures in the West were much greener than in the GDR. This left the GDR in a precarious situation - right from its beginning. The lack of stability favoured the emergence of a particularly rigid government and police system. The Berlin-Wall (actually an intra-German wall!) symbolized this evidently. In May 1989 Hungary opened its borders with Austria and thus cut the first hole in the Iron Curtain which shielded Eastern Europe from Western Europe. But when the CSSR then closed its borders with Hungary - on East-Berlin's instigation, Germans who wanted to leave East Germany for the West found a new outlet. They took refuge in West German Embassies in Eastern Europe and asked for a West German passport and consular protection - which they were entitled to as Germans. This happened in the summer of 1989 in particular in Prague and Warsaw, but as well in other capitals and even in East Berlin, in the West German Permanent Representation. 


\section{Calls for German Unity}

In Germany, the regular Monday demonstrations and other popular mass events, the rising number of Germans fearlessly applying for permission to leave the GDR and its increasingly desolate economic situation led on 9 November 1989 to the fall of the Berlin Wall. However, the opening of the Brandenburg Gate did not just open safety valves and then return to East German normalcy as the communist regime might have hoped initially. On the contrary - it really opened the dams widely and irreversibly. The free flow of East Germans to West Germany led to an unprecedented exodus. Until end of 1989 more than 340.000 Germans had left the GDR for West Germany, over 2 percent of the GDR's entire population.

The dynamics of this situation overburdened both German states, economically, socially and politically. For politicians in East and West there was no doubt that something had to happen to stop this mass exodus. But East Germans were not sure about the durability of the new situation. They had no confidence in the regime - still staffed by the old communist nomenclatura. And they did not want to wait more years for economic prosperity realized in the West. They wanted the hard German mark immediately - the symbol of West German post-war success and achievement, which for more than 40 years they had enviously observed just as onlookers.

In this situation the first tender blossoms of thinking the unthinkable occurred. The first calls for German unity did not come from politicians who could not muster the fantasy, the courage or even the will for a United Germany. It came from the East Germans - who changed their street-slogan from "we are the people" (before the wall fell) to "we are one people" in the time after. Helmut Kohl was one of the first politicians who grasped this signal and turned it into a bold (though from hindsight still cautious) move to bring the two German states together. On 28 November 1989 he proposed in Parliament a 10 points program, with a long-term perspective towards a confederation of the two German states.

Kohl's move - not at all coordinated with the Four allied Powers, not even with his own Foreign Minister Genscher - created considerable irritation, particularly among his European colleagues in Paris, London and Moscow. Some grim muscle-flexing (using the Four Power rights and responsibilities) - like impromptu visits by President Mitterrand in Kiew and East Berlin and by PM Thatcher in a number of European capitals followed. There was even a strangely anachronistic meeting of the four allied ambassadors in the Berlin Control Council's building - a symbol of the Four Powers' occupational role and not used since 18 years - which expressed the nervousness and resistance towards what was soon accepted as unavoidable. But in the end all four Powers - the Soviet Union last - jumped onto the bandwagon of German unity - not the least in order to shape events instead of being overthrown by the popular movement's tidal force.

The Four Powers - with their different political weight, geographical position and historical background - emphasised different aspects in their basic approval to enter German unification on an operational level. The US took earliest an easy and constructive approach to German Unity - mainly strategy, security and stability related. They were eager to preserve or to bring about a sound and stable European architecture, with full NATO membership of the united Germany. France as Germany's closest neighbour was particularly anxious to firmly embed a united Germany into a more deeply integrated European Union. The idea of an economic 
and currency union certainly got a vital boost from the French position. France furthermore wanted a rock-solid recognition of the united Germany's boundaries as final, particularly with Poland. The UK had concerns like no other of the western powers by its age old fear of destabilization on the continent and possible distortions of the continent's power balance by a weighty, powerful, free-floating united Germany. It saw NATO membership and a further enlargement of the European Community as the best means to achieve a managed balance and stability for the European continent with the German weight balanced by a large network of European partners. The Soviet Union naturally had the most difficulties accepting German unity. It was mainly interested in security related aspects, the military status of a united Germany and even in its neutrality. Furthermore, the Soviets emphasized border guarantees and territorial claims and wanted to embed the united Germany in a more developed and institutionalized CSCE process.

\section{$2+4$ enters the stage}

These short descriptions outline only very roughly the complex positions of the respective actors. There was hectic interaction of diplomatic and political talks and events - from December 1989 until early February 1990 - to translate the framework of the various positions into a procedural concept. Two major milestones were the plan for an economic, monetary and social union, announced by the two German states on 7 February and the visit by Kohl and Genscher to Moscow on the 10/ 11 February 1990. In Moscow the German leadership received the Kremlin's assurance that it was for the Germans alone to decide on the timing of unification and on the specific way to reach it. The way to the $2+4$ talks was free. But the structure of the talks realised in the end German essentials:

2+4 and not only 4: No four power negotiations about Germany - with a minor status for the two German states sitting at the side table (as was the case in 1954). This was unthinkable for all Germans and any hint in that direction was clearly refused. Therefore these were talks with Germany, on an equal level, not talks about Germany.

$2+4$ and not $4+2$ The negotiations were first and foremost a matter of the 2 German states, to be talked about with the four Allied Powers. The first ranking 2 expressed the centrality of the two German states in these negotiations.

$2+4$ and not $2+X$ Limitation to the Four Powers - in recognition of their continuing legal rights and responsibilities related to Berlin and Germany as a whole. This meant: no expansion of the talks to other neighbours, in particular no Conference about a Peace Treaty with Germany. Such a conference could have included more than 100 states all over the world and would have assured years, if not even decades of negotiations. However, Poland for its unique geographical and historical situation with Germany would have to be given particular consideration.

External only It was a clear understanding that these talks were limited to the external aspects of Germany unity. Internal aspects - like the intra-German unification Treaty, the choice of how unification happened and questions like the German economic and currency union - were exclusively a matter of the two German states. On this line the 6 foreign ministers announced in Ottawa on the margins of the NATO/WP conference about “open skies," on 13 and 14. February 1990, that they will meet and talk about external aspects of German unity, "including security aspects of neighbouring states." This was the first time the $2+4$ formula entered the public. 


\section{The $2+4$ process starts}

The $2+4$ process has been described as a roundtable with sharp corners. What were the sharpest corners of this roundtable?

- Membership in military alliances: The two German States were major pillars in their respective military alliances, in NATO and Warsaw Pact. What would happen to their respective memberships at unification? Would the united Germany be member in either NATO or Warsaw Pact (though nobody thought of the latter question seriously), would it be neutral or even member in both alliances (as Gorbachev had even proposed once)?

- Stationed Troops: What should happen with the foreign soldiers stationed on both sides of the intra-German border? The real concern for both German states was however the Red Army only which had 380000 Soviet troops stationed in the GDR. Would the Soviets give up their military - and political leverage in Central Europe and if: when and how could it be made sure, that they left, in a structured process and with a fixed schedule?

- Borders of the united Germany: Where would the external borders of the united Germany be? This was a question particularly sensitive for the German border with Poland. The Federal Republic of Germany had not formally given up its legal position with respect to the former German territories, which after the war became part of Poland (mainly Pomerania, Silesia and Eastern Prussia). No responsible German politician seriously thought about asking these large territories back - but symbolically it was an important domestic policy issue in Germany.

- Central European Stability: Hiding behind this is the "Deutsche Frage," the "German question." With its unification Germany would be by far the most populous and in a tangible perspective the economically most powerful country in Europe. This had historically proved to be a major challenge for Europeans throughout the 20th century as witnessed by two World Wars. How could a repetition of historical precedents be prevented? The united Germany's firm embedding in the European Union was emphasized particularly by France. But NATO membership was an effective stabilizing constraint too, an argument which would play out later in the talks. The Soviets however pressed for more extended and institutionalized CSCE structures, with their own participation

- Full sovereignty of the united Germany The sovereignty of the two German States was limited by the four powers' rights. Though both states had gained sovereignty regarding their own affairs since the Fifties, the Four Power had upheld their rights and responsibilities relating to Berlin and Germany as a whole. Could these rights be totally abolished to avoid any continuing "droit de regard" by the Four Powers? For the German side there was only one option: total abolishment of the Four Power status from day 1 of unification, no perennial special status for Germany, which would have singled it out in the international community ever after.

\section{The $2+4$ negotiations}

Talks took place on the level of senior civil servants (mainly political directors) who prepared the four meetings which then were held on the Foreign ministers level, in Bonn, East Berlin, Paris (with Poland) and finally in Moscow on 12. September. The 
start of the talks set a number of parallel processes into motion. I will limit myself to two main aspects:

\section{Polish Border}

This question was one of the most sensitive political questions, for Germany as well as for Poland and other neighbours, particularly France. In Germany no responsible politician questioned seriously the finality of the German external borders. However, the Potsdam Agreement of J uly 1945 between the allied Powers had stated, that the final delimitation of Poland's Western frontier should be made dependent on a peace settlement. The German Chancellor referred to this legal aspect when avoiding any clear commitment towards the finality of the existing German/ Polish border. This was apparently for tactical, domestic reasons, since the Federal elections in West Germany were due end 1990 and Kohl was afraid of large gains for a radical right wing party if he "gave away" one fifth of the former German territory.

However, after getting under increased pressure externally and internally for his position, Kohl reached an agreement in the governing coalition on the 6th March 1990 which settled the issue domestically in accordance with what Germany's neighbours expected - and in line with what the overwhelming majority of Germans had approved anyway. In the $2+4$ ministerial in Paris on 17J uly, 1990, with the Polish Foreign Minister Skubiczewski participating, this issue was settled internationally too and was dealt with in Art. 1 of the $2+4$ Treaty. The Germans committed to concluding a border treaty with Poland after unification and the achievement of full German sovereignty. This treaty was signed on the 14th November 1990 in Warsaw and ratified end of 1991, after signature of a second German - Polish Treaty on good neighbourliness, partnership and cooperation.

\section{Military status of the united Germany}

This issue emerged as the make-or break-question of $2+4$ (right until the last night before its signature!). Whereas the two German states and the Western Powers insisted on NATO membership for the united Germany, the Soviet Union clearly had the united Germany's neutralization in mind. To bring these opposing positions in alignment developed into one of the professionally most exciting challenges of diplomatic history.

The West's argument against neutralization was clear: a neutral Germany in its precarious geopolitical position would cease to be embedded in a security arrangement. Alone, lacking the support of its former allies it would have to arm itself more heavily than ever before. Politically it would freely float around in central Europe - and the "German Question" would loom again on the horizon! And this was not only a Western argument: Germany's neighbours and the Soviet Union's allies Poland, Czechoslovakia and Hungary fully shared this argument - leaving the Kremlin isolated in this question.

However, Gorbachev had a point. Extending the NATO territory to the GDR meant a decisive shift of balance in Central Europe. How should Gorbachev seriously sell such a concept to the hardliners in Moscow, reversing one of the most important results of the second World War? Wouldn't the West ask the Soviet leader to commit political suicide? Even the US with their staunch line on the alliance seemed to be impressed by this dilemma and reflected shortly on an only associated membership of Germany in NATO. The German FM Genscher in an address in Tutzing/ Bavaria end of J anuary 
1990, took a different approach. He advanced the idea that Germany should stay in NATO but that NATO structures should not be extended to the GDR territory.

However, the Soviet Union rejected vigorously any link between NATO and the united Germany, throughout the first ministerial $2+4$ in Bonn, 4/ 5 May 1990. This was one of the main reasons too, for the Soviet rejection of the approach by which the two German states wanted to reach their unity: not by a merger, setting up a new constitution and rules for the united Germany, but rather by a provision in the West German constitution (the Basic Law) which allowed the simple accession to the Federal Republic of Germany of other parts of Germany (Art. 23). By such accession of the GDR territories they would nearly automatically take over the international obligations of the Federal Republic of Germany, including NATO and EC membership. Though this was an intra-German question only - Moscow rejected the accession via Art. 23 because of its international consequences.

After the first (and last) free elections in the GDR on 18 March 1990, however, the two German states confirmed Art. 23 of the constitution and accession as the way they would take. For them there was no feasible alternative to reaching unity expeditiously in view of the quickly increasing disintegration of the GDR. Now Moscow dropped its opposition against instant unification under Art. 23. Instead it brought up a proposal to decouple internal and external unification, meaning that full sovereignty for the united Germany would be postponed - at least for 5 years as Shevardnadse later specified. Kohl rejected this proposal as it could have meant partial neutralization of Germany. Further Soviet suggestions included Germany to stay out of NATO's integrated structure or even double membership of the united Germany in both military alliances, NATO and Warsaw Pact.

But despite these rear guard battles a package deal - more or less on the lines of the later $2+4$ Treaty - began to emerge:

- NATO forces and structures would not be advanced into GDR territory;

- Soviet troops would stay in the GDR for a transitional period;

- the prosperous Germany would help the Soviets with problems arising from the troops withdrawal, in particular housing;

- limitations of the united Germany's armed forces strength would be introduced and

- further agreements regarding NATO's character and strategy and an institutionalized setup of the CSCE rounded off the package.

This package deal was firmly pushed through by the Western side, showing at the same time its good will to solve understandable Soviet concerns. The NATO ministerial meeting on 5 and 6J une 1990 in Turnberry Scotland and the London Declaration by heads of state and government ( $6 \mathrm{~J}$ uly) sent out an unprecedented signal of friendship and cooperation to Moscow and made a number of specific arms control proposals which did not fail to impress the Soviet Union. The "Turnberry Message" essentially anticipated the London declaration and helped Gorbachev in time to convince his growing critics ahead of the 28th Party Congress of the Soviet Communist Party in early J uly 1990.

The breakthrough followed in the meeting between President Gorbachev and Chancellor Kohl in the Caucasus from 14 - 16th J uly. Here the two statesmen had a number of talks with decidedly personal-private character. At the end Gorbachev conceded, that the united Germany would gain full sovereignty upon unification and 
would be free to decide by itself whether it wanted to belong to a military alliance. Kohl made it clear that from his view this would be the Atlantic alliance. An agreement would be concluded with the Soviet Union about the withdrawal of Soviet troops within three to four years. NATO structures would not be extended to the former GDR's territory as long as Soviet troops were still present there. Germany would commit - in Vienna - to reduce its forces to 370.000. It would confirm its renunciation of weapons of mass destruction and its membership to the NPT.

With this breakthrough the $2+4$ negotiations entered the final stretch. The "Treaty on the Final Settlement with Respect to Germany" was signed in Moscow on the 12th September 1990, in the Hotel Oktjabrskaja. The foreign minister of the Four Powers suspended their allied rights and responsibilities on the 1st October. The way for a united and sovereign Germany on the 3rd October 1990 was free.

\section{Looking back}

Looking back we can confirm what Genscher said: The $2+4$ Treaty is the most important and promising agreement that the Federal Republic of Germany had ever concluded. Within 7 months of negotiations it totally turned around a political and legal situation, which seemed to be irreversibly locked by history. However, the achievement of many politicians and diplomats would not have been possible without the courage and the steadiness of the East German people. They created and upheld the political pressure, which served directly the speed of negotiations and the search for compromise. Without this speed the negotiations might have stranded in a situation where Gorbachev lost more and more ground to his opponents in the Soviet leadership and where he or his successor would not have been anymore in a situation to pave the way for German unity. In the end luck played its role, too. 